accurately the characters under investigation : for example, mental defect can be, and is, defined in several ways, legally, clinically, psychologically, etc. In the legal sense it is a social concept, for according to the law the feeble-minded are "persons in whose case there exists from birth or from an early age mental defectiveness so pronounced that they require care, supervision, and control for their own protection or for the protection of others ; or, in the case of children, that they, by reason of such defectiveness, appear to be permanently incapable of receiving proper benefit from the instruction in ordinary schools". However satisfactory this may be as a legal definition, it is useless both biologically and psychologically, for in the absence of any definition of mental defectiveness or arrested mental development, it means just inability to look after oneself and one's affairs without proper supervision. If social environment becomes more complex and makes higher and higher demands on natural capacity, then, unless that capacity improves, the proportion of feebleminded must increase. Some think that feeblemindedness is increasing, and that this is due to differential birth-rate, but it is equally possible that the cause lies in the increasing complexity of civilised life : intellects that could live happily in a simpler environment may be finding the complexities of modern civilisation too much for them : there can be little doubt that to-day bigger demands are being made on children in the 'ordinary schools' than were made on them fifty years ago.

The clinical varieties of mental deficiency which medical men meet-mongolism, cretinism, microcephaly, hydrocephaly, etc.-are distinguished by anatomical rather than by either social or psychological characters. Psychologically, mental deficiency is usually defined in relation to performance at intelligence tests: the legal mental defective usually has an intelligence ratio below seventy, so this figure is often taken as marking the line that separates the mental defective from the normal. This is an arbitrary method of defining mental deficiency ; it has the merit of precision, but it is a precision which may be misleading when we begin to investigate its genetic basis, for it is possible that feeble-mindedness may be due to one or more of a large number of genetic factors ; there may be different forms of feeble-mindedness which are not distinguishable by means of intelligence ratios.

\title{
From Log Cabin to Royal Observatory
}

\section{By Prof. Allan Ferguson}

$\mathrm{T}$ HE British Association has seen many excursions and occasions, but few can compare, in real romantic interest, with the excursion which set out from the Marischal College in Aberdeen on Monday, September 10, to attend the unveiling of the Lamont memorial above Braemar. Most of us had a vague notion, based mainly on the ' $\mathrm{A}$ ' appearing on our excursion ticket, that Lamont had some connexion with physical science, possibly with astronomy. A few said, "Why Braemar? Wasn't Lamont a German ?" ; and, did one seek information concerning Lamont's life and labours from an eminent astronomer, invariably he

"Dallied with his golden chain, And, smiling, put the question by."

The setting was perfect. The road through Braemar climbs along a precipitous hillside and looks down on the Dee falling ever farther and farther below. Four or five miles past the spot where, as tradition tells, the Standard on the Braes o' Mar was up and streaming rarely on a September day in 1715 , is the clachan of Corriemulzie where Lamont was born on December 13, 1805 , and a couple of miles farther on is the village of Inverey where he had his schooling. Here, on a natural platform a few yards above the road, stands a severe obelisk of grey granite bearing, below a cross of St. Andrew carved on its face, the inscription

$$
\begin{gathered}
\text { THIS STONE } \\
\text { COMMEMORATES } \\
\text { JOHN LAMONT } \\
\text { 1805-1879 } \\
\text { WHO WAS BORN AT } \\
\text { CORRIEMULIE. } \\
\text { HIS NAME IS WRITTEN } \\
\text { IN THE HISTORX OF SCIENCE } \\
\text { AS } \\
\text { JOHANN VON LAMONT } \\
\text { ASTRONOMER ROYAL OF BAVARIA. }
\end{gathered}
$$

On the back of the stone, below a representation of the constellation of Orion, is the text, "Day unto day uttereth speech, and night unto night showeth knowledge", which text is repeated on the west and on the east sides in Gaelic and in German.

The memorial was as yet hidden under a canvas covering, and at four o'clock Prince and Princess Arthur of Connaught arrived and were escorted to the memorial, the pipes playing the Lamont march. The president of the British Association, 
Sir James Jeans, explained the occasion in a few fitting words, Princess Arthur unveiled the memorial, and words of thanks concluded the simple ceremony.

What is the link that binds the story of the village lad of Corriemulzie to that of the Bavarian astronomer of world-wide reputation? This, that at Ratisbon in Bavaria existed a college of Scottish Benedictine monks which from time to time took charge of youngsters from Scotland in order to educate them for the priesthood. John Lamont was so chosen, and on an October morning of 1817 we may picture the twelve-year-old wood forester's son setting out in a farm cart for what was then a toilsome three days' journey to Aberdeen-a road which our motor coaches covered in less than three hours. Arrived at Aberdeen, the travellers set sail for Rotterdam, and thence made their way up the Rhine to their destination. Followed eleven years of hard study, and at the end of that period Lamont, who had discovered a capacity for mathematics, decided that astronomy rather than the priesthood was his vocation. Accordingly, in March 1828 he was appointed assistant astronomer in the Royal Observatory at Bogenhausen, near Munich, of which observatory at that time Prof. Soldner was conservator. In 1835, two years after the death of Soldner, Lamont succeeded to the position of conservator, and in 1852 , the year of his election as a foreign member of the Royal Society, he was appointed to the chair of astronomy at Munich*. On August 6, 1879, he died at Munich at seventy-four years of age. The John Làmont of Braemar merged his identity very completely in that of Johann von Lamònt, the Bavarian astronomer; indeed, the late Earl of Crawford, who consulted Lamont in 1873 concerning the equipment of an expedition to observe the transit of Venus, furbished up his German for the interview, and was not a little surprised to find his introductory speech answered in good Aberdeen Scots.

What were Lamont's principal contributions to astronomical science? His observatory provided him with a refracting telescope of $10 \frac{1}{2}$ inches aperture and 15 feet focal length, and with this instrument he made observations of Titania and Oberon-two satellites of Uranus-and hence deduced a value for the mass of Uranus in terms of that of the sun. Reduced to its simplest form, the calculation is, of course, simple. One writes down the force between the planet $(P)$ and the satellite $(M)$ as $G . P M / r^{2}$ and equates it to the mass-acceleration $\left(M v^{2} / r\right)$ of the satellite. A similar equation holds for the planet $(P)$ and the

* I have not noticed, in the official obituaries which $I$ have consulted, the title "Astronomer Royal of Bavaria" as representing Lamont's official position, which seems to have been that of "Conservator of the Royal Observatory". sun $(S)$ in terms of the velocity $(V)$ of the planet and the radius $(R)$ of its orbit. Hence, by dividing the two equations, we have the numerical value of the ratio $P / S$ if we know the speeds and orbits of satellite and planet. Lamont's value for this ratio was 1/24905. Of the determinations made during his lifetime the most important are those of Bouvard who, in 1821, obtained the value $1 / 17918$ from a consideration of the perturbations of Jupiter and of Saturn; of von Asten, who in 1871, working on observations of the two exterior satellites made by Struve, Lassell and Marth as well as those of Lamont, deduced the value $1 / 22020$; of Copeland, in 1875, who, using Lord Rosse's telescope, found a value of $1 / 24000$; and of Holden, in 1878, who, from observations made in 1875-76, obtained a mean value of $1 / 22600$. Taking from modern tables the mass of Uranus as $87 \cdot 7 \times 10^{24}$ kilograms, and that of the sun as $1.984 \times 10^{30}$ kilograms, the ratio is $1 / 22620$.

In 1835 Lamont made a long series of observations on Halley's comet, and in 1836 he carried out observations on the second and third satellites of Saturn and deduced the elements of their orbits. He observed several total eclipses of the sun, and subscribed to the view that the red prominences were produced by elouds or other vapours in the earth's atmosphere.

Lamont has many claims to be regarded as a pioneer in the science of terrestrial magnetism, taking, as he did, a leading part in establishing that concerted system of magnetic observations which was inaugurated about 1840. The bent of his work is indicated by the title of the first paper which he devoted to this subject-"Bestimmung der Horizontal-Intensität des Erdmagnetismus nach absolutem Maase" and he followed this up by a long series of papers devoted to observations and instruments.

Lamont's most massive contribution to astronomical science is contained in a six-volume catalogue of telescopic stars, mainly of the eighth and ninth magnitudes. His labours were confined to a broad belt round the celestial sphere, extending from $27^{\circ} \mathrm{N}$. to $33^{\circ} \mathrm{S}$. of the equator of that sphere, although most attention was paid to stars on the belt extending from $15^{\circ} \mathrm{N}$. to $15^{\circ} \mathrm{S}$. of the equator. In this region no fewer than 34,764 stars were observed, their positions being mapped out in ten catalogues, each extending over a belt about six degrees in breadth. It may be remarked that on two occasions he unwittingly observed the planet Neptune-on October 25, 1845, and September 7, 1846. Galle's identification of the planet was made on September 23, 1846.

That, in brief, is the story of quiet achievement which the granite stone on Deeside will com. memorate for centuries to come. 